\title{
RULE 10b-5: THE REJECTION OF THE BIRNBAUM DOCTRINE BY EASON $v$. GENERAL MOTORS ACCEPT ANCE CORP. AND THE NEED FOR A NEW LIMITATION ON DAMAGES
}

In Eason v. General Motors Acceptance Corp., ${ }^{1}$ the Seventh Circuit became the first circuit to reject the long-standing requirement that plaintiffs bringing a private action under Securities and Exchange Commission rule $10 \mathrm{~b}-5^{2}$ must be either purchasers or sellers of securities as required by the rule announced in the 1952 landmark decision of Birnbaum v. Newport Steel Corp. ${ }^{3}$ In 1969, Bank Service Corporation purchased the automobile leasing business of Dave Waite Pontiac, Inc. Waite Pontiac had financed the purchase of the leased automobiles through General Motors Acceptance Corporation (GMAC), and the consideration given by Bank Service included, in addition to 7,000 shares of its stock, the assumption of the leasing busmess' debts to GMAC; shareholders of Bank Service personally 1974).

1. 490 F.2d 654 (7th Cir. 1973), cert. denied, 42 U.S.L.W. 3609 (U.S. Apr. 22, NOTE:

HEREAFTER THE FOLLOWING CITATIONS WILL BE USED IN THIS

A. Bromberg, Securities LaW: Fraud (1973) [hereinafter cited as A. Brombero];

L. Loss, Securrties Regulation (2d ed. 1961) [hereinafter cited as L. Loss];

L. Loss, SecurtTies Regulation (Supp. 1969) [hereinafter cited as L. Loss (Supp. 1969)].

2. Securities and Exchange Commission Rule 10b-5, 17 C.F.R. $\S 240.10 \mathrm{~b}-5$ (1973), provides:

It shall be unlawful for any person, directly or indirectly, by the use of any means or instrumentality of interstate commerce, or of the mails or of any facility of any national securities exchange,

(a) To employ any device, scheme, or artifice to defraud,

(b) To make any untrue statement of a material fact or to omit to state a material fact necessary in order to make the statements made, in the light of the circumstances under which they were made, not misleading, or

(c) To engage in any act, practice, or course of business which operates or would operate as a fraud or deceit upon any person, in connection with the purchase or sale of any security.

Rule 10b-5 was promulgated pursuant to section 10(b) of the Securities Exchange Act, 15 U.S.C. \& $78 \mathrm{j}(\mathrm{b})(1970)$. See notes 14-18 infra and accompanying text.

3. 193 F.2d 461 (2d Cir.), cert. denied, 343 U.S. 956 (1952). See notes $25-28$ infra and accompanying text. 
guaranteed the leasing business' notes payable to GMAC. Subsequently, the leasing business failed, and GMAC brought suit in state court against the Bank Service shareholders seeking to recover on their guarantees. Accusing both Waite Pontiac and GMAC of fraud in connection with the transaction, Bank Service shareholders brought a federal action based on section $10(\mathrm{~b})$ and rule $10 \mathrm{~b}-5$ seeking rescission of the guarantees. Their coinplaint was dismissed by the trial court on the grounds that the plaintiffs lacked standing ${ }^{4}$ since they were neither purchasers nor sellers of securities. The Seventh Circuit reversed; framing the issue as the validity of the so-called Birnbaum doctrine, ${ }^{5}$ the court stated that neither the Constitution nor any policy consideration inandated the purchaser-seller requirement. Finding that such a requirement improperly restricts the coverage of rule $10 \mathrm{~b}-5$, the court unequivocally rejected the Birnbaum doctrine. ${ }^{6}$

The stock market crash of 1929 , and the depression which followed, produced public sentiment in the 1930's for reform of the nation's securities markets. ${ }^{\top}$ In response, President Roosevelt in 1934 recommended to Congress

the enactment of legislation providing for the regulation by the Federal Government of the operations of exchanges dealing in securities . . . for the protection of investors, for the safe-guarding of values, and, as far as it inay be possible, for the elimination of unnecessary, unwise, and destructive speculation. ${ }^{8}$

As a result, ${ }^{9}$ Congress enacted the Securities Exchange Act of $1934^{10}$

4. In a technical sense, standing refers to a constitutional requirement which must exist in order for a court to have jurisdiction over a case. A party bringing an action must show a personal stake in the outcome of the dispute he seeks to have adjudicated. See Flast v. Cohen, 392 U.S. 83, 101 (1968), citing Baker v. Carr, 369 U.S. 186, 204 (1962). If this is not shown, the action does not meet the "case or controversy" requirement of article III of the Constitution and the court would not have jurisdiction to hear the case. The Eason court correctly stated that standing in this constitutional sense is not involved in the question of whether the purchaser-seller requirement is valid. However, the word "standing" has been used repeatedly in cases after Birnbaum to refer to the status of a plaintiff who is within the protection of rule 10b-5. Given the convenience of the term and its previous usage, "standing" will be used in this sense throughout this Note.

5. The court stated that "[t]he question which is thus presented is whether, notwithstanding the fact that they were neither purchasers nor sellers of a security, plaintiffs may obtain relief under Rule 10b-5." 490 F.2d at 656.

6. The court concluded: "We lold that [the purchaser-seller limitation] is not a part of the law of this circuit." Id. at 661.

7. See, e.g., H.R. REP. No. 1383, 73d Cong., 2d Sess. 2 (1934); 1 L. Loss 119-21; Note, The Securities Exchange Act of 1934, 83 U. PA. L. REv. 255 (1934).

8. H.R. REP. No. 1383, supra note 7, at 2.

9. Congress had previously enacted the Securities Act of 1933, 15 U.S.C. $\$ 77$ (1970), the aim of which was to provide investors with material information related 
(Exchange Act), for the purpose, according to the Senate Committee on Banking and Currency, of "purging the securities exchanges of those practices which have prevented them from fulfilling their primary function of furnishing open markets for securities where supply and demand may freely meet at prices uninfluenced by manipulation or control."11 To accomplish this purpose, it was necessary for the Act to be broad in scope. ${ }^{12}$ As a part of this broad regulation of the securities exchanges, section $10(b)^{13}$ was included as a catchall provision designed to prevent manipulative devices and practices.

The Exchange Act, while denominating what subjects are proper for regulation, left the promulgation of rules and regulations to the newly formed Securities and Exchange Commission (SEC). ${ }^{14}$ Under this authority, the SEC in 1942 promulgated rule $10 \mathrm{~b}-5^{15}$ to aid in the implementation of section 10(b). Federal securities law up to that time had failed to prohibit the fraudulent purchase of securities by non-brokers. ${ }^{18}$ In announcing rule $10 \mathrm{~b}-5$, the SEC stated

to securities offered for public sale and to prohibit misrepresentation, fraud and deceit in sales of securities. R. Jennings \& H. Marsh, Securittes Regulatton 34 (3d ed. 1972).

10. 15 U.S.C. $\& 78 \mathrm{a}$ (1970). For analyses of the Excliange Act written shortly after the Act became law, see Tracy \& MacChesney, The Securities Exchange Act of 1934, 32 Mich. L. Rev. 1025 (1934); Note, The Securities Exchange Act of 1934, 23 GEo. L.J. 93 (1934). See also Note, The Securities Exchange Act of 1934, supra note 7.

For a general discussion of the historical background of the Exchange Act and section $10(\mathrm{~b})$ and rule $10 \mathrm{~b}-5$, see $1 \mathrm{~A}$. BROMBERG $\$ 2.2$.

11. S. Rep. No. 1455, 73d Cong., $2 \mathrm{~d}$ Sess. 81 (1934). See also 15 U.S.C. $\S 78 \mathrm{~b}$ (1970).

12. See H.R. REP. No. 1383, supra note 7, at 6.

13. Section 10 of the Securities Exchange Act, 15 U.S.C. $\$ 78$ j (1970), provides: It shall be unlawful for any person, directly or indirectly, by the use of any means or instrumentalities of interstate commerce or of the mails, or of any facility of any national securities exchange-

(b) 'To use or employ, in counection with the purchase or sale of any security registered on a national securities exchange or any security not so registered, any manipulative or deceptive device or contrivance in contravention of such rules and regulations as the Commission may prescribe as necessary or appropriate in the public interest or for the protection of investors.

14. See 15 U.S.C. $\& 78 w(a)$ (1970). The House committee report stated that the

Exchange Act

leaves to the administrative agencies the determination of the most appropriate form of rule or regulation to be enforced. In a field where practices constantly vary and where practices legitimate for some purposes may be turned to illegitimate and fraudulent means, broad discretionary powers in the administrative agency have been found practically essential. H.R. REP. No. 1383, supra note 7, at 6-7.

15. See note 2 supra.

16. Section 17(a) of the Securities Act of 1933 prohibitcd fraud in the offer or sale of securities. 15 U.S.C. \& 77q(a) (1970). Likewise, rule 15c1-2, 17 C.F.R. \& 240.15c1-2 (1973), promulgated under section 15(c)(1) of the Exchange Act, prohib- 
that its purpose was to close "a loophole in the protections against fraud administered by the Commission by prohibiting individuals or companies from buying securities if they engage in fraud in their purchase." 17 Thus, the original purpose of rule $10 \mathrm{~b}-5$, although unstated in the rule itself, ${ }^{18}$ was the protection of sellers of securities from fraud.

Initially, rule 10b-5 generated little excitement; apparently the potential it possessed to becoine an important anti-fraud device was not immediately recognized. ${ }^{19}$ In the past twenty years, however, the growth in the scope of the rule's application has been spectacular; it has been estimated that presently rule 10b-5 appears in onethird of all federal securities cases, ${ }^{20}$ and the Supreme Court has commented that "§ $10(\mathrm{~b})$ and Rule $10 \mathrm{~b}-5$ may well be the most litigated provisions in the federal securities laws . . . ."21 Thus, section 10 (b) and rule 10b-5 have developed into major tools of the federal securities law for preventing and punishing fraudulent activities in connection with the purchase and sale of securities.

Of great importance in stimulating the increased application of section 10(b) and rule $10 \mathrm{~b}-5$ was the recognition of a private right of action under section $10(\mathrm{~b})$. The Exchange Act itself does not mention such a right; however, in 1946 the first reported case involving rule 10b-5 liability, Kardon v. National Gypsum Co., ${ }^{22}$ held that a person injured as a result of a violation of section 10(b) could bring a civil suit for damages, ${ }^{23}$ and this private right of action has become universally recognized..$^{24}$

ited fraud in the purchase or sale of securities by brokers. However, there was no prohibition against the fraudulent purchase of securities by non-brokers. 1 See $3 \mathrm{~L}$. Loss 1426-27; Note, S.E.C. Action Against Fraudulent Purchasers of Securities, 59 Harv. L. Rev. 769, 770 (1946).

17. SEC Securities Exchange Act Release No. 3230 (May 21, 1942). This release can be found in 3 A. Bromberg 295 (App. B).

18. See 3 L. Loss 1469 \& n.87. For a general discussion of the original purposes of rule $10 \mathrm{~b}-5$, see $1 \mathrm{~A}$. BRoMBERG \& $2.2(420)$.

19. See 1 A. BROMBeRg $\$ 2.2(420)$. Section $10(\mathrm{~b})$. likewise aroused little controversy when it was proposed; few comments were made concerning it during congressional consideration of the Exchange Act. Id. $\$ 2.2(330)$.

20. Id. $\$ 2.5(6)$. For an indication of the expanding frequency with which rule 10b-5 cases are being brought, see 6 L. Loss 3559 (Supp. 1969).

21. SEC v. National Sec., Inc., 393 U.S. 453, 465 (1969).

22. 69 F. Supp. 512 (E.D. Pa. 1946).

23. For a general discussion of the implied right of action and various rationales supporting it, see 1 A. BromBERG $\$ 2.4(1)-(2) ; 3$ L. Loss 1557-63.

24. The Supreine Court has recognized this implied private right of action. See Superintendent of Ins. v. Bankers Life \& Cas. Co., 404 U.S. 6, 13 n.9 (1971); cf. J.I. Case Co. v. Borak, 377 U.S. 426, 430, 433 (1964) (private right of action under section 14 of Exchange Act recognized). 
Since private rights of action under section 10(b) are implied, there is no express statutory pronouncement as to who has standing to bring such suits. However, in 1952 Judge Augustus Hand, speaking for the Second Circuit, held in Birnbaum v. Newport Steel Corp. ${ }^{25}$ that only defrauded purchasers or sellers of securities had such standing. In determining whether the plaintiffs had standing to bring a section 10(b) action, Judge Hand emphasized the original purpose of rule 10b-5. The court rejected plaintiffs' argument that the class of plaintiffs under rule $10 \mathrm{~b}-5$ was not intended to be limited to purchasers or sellers of securities but that rule $10 \mathrm{~b}-5$ was meant to supplement the common law liability of persons who breach the fiduciary duties imposed by their corporate positions; it pointed out that rule $10 \mathrm{~b}-5$ was created not for the general protection of shareholders but to provide federal protection for purchasers and sellers of stock. ${ }^{20}$ The court held for the defendants, indicating that section $10(\mathrm{~b})$

was directed solely at that type of misrepresentation or fraudulent practice usually associated with the sale or purchase of securities rather than at fraudulent mismanagement of corporate affairs, and that Rule X10b-5 extended protection only to the defrauded purchaser or seller. ${ }^{27}$

In other words, only purchasers or sellers of securities could bring a private action under rule $10 \mathrm{~b}-5 .^{28}$

The Birnbaum court's analysis of the SEC's purpose in adopting rule $10 \mathrm{~b}-5$ seems sound. Before Eason, all circuit courts that had faced the issue followed the Birnbaum doctrine, ${ }^{29}$ and Professor Loss las

25. 193 F.2d 461 (2d Cir.), cert. denied, 343 U.S. 956 (1952). Birnbaum arose out of the dealings of one Feldmann, the president and forty percent shareholder of Newport Steel Corporation. Follansbee Steel Corporation had offered to merge with Newport in a transaction whose terms would have been quite profitable to the shareholders of Newport. However, Feldmann, acting in his capacity as president, rejected this offer and sold his controlling block of stock to a third company for about twice its then market value. Plaintiffs, shareholders of Newport who had apparently purchased their shares well before the sales negotiations and had continued to hold thein after Feldmann's sale, alleged that representations made in letters sent to Newport stockholders by Feldmann concerning the Follansbee offer violated rule 10b-5 and brought a class action suit under section $10(\mathrm{~b})$ and rule 10b-5. Id. at 462 .

26. Id. at 463 . See also notes 16-18 supra and accompanying text.

27. Id. at 464 .

28. For discussion of this purchaser-seller requirement, see $1 \mathrm{~A}$. Bromberg $\$ \$ 4.7$ (560)-(569); 3 L. Loss 1468-73; 6 L. Loss 3617-20 (Supp. 1969).

29. See, e.g., Landy v. FDIC, 486 F.2d 139 (3d Cir. 1973), cert. denied, 42 U.S.L.W. 3593 (U.S. Apr. 22, 1974); Mount Clemens Indus., Inc. v. Bell, 464 F.2d 339, 342 \& n.5 (9th Cir. 1972); Herpich v. Wallace, 430 F.2d 792 (5th Cir. 1970); Simmons v. Wolfson, 428 F.2d 455 (6th Cir. 1970), cert. denied, 400 U.S. 999 (1971); City Nat'l Bank v. Vanderboom, 422 F.2d 221 (8th Cir.), cert. denied, 399 U.S. 905 (1970); Iroquois Indus., Inc. v. Syracuse China Corp., 417 F.2d 963 (2d Cir. 1969), 
stated that Birnbaum was "basically correct."30 Yet from the beginning Birnbaum has aroused a storm of controversy. Commentators have criticized the decision, ${ }^{31}$ and the SEC has recommended that the purchaser-seller requirement be rejected. ${ }^{32}$ The dissatisfaction with the Birnbaum doctrine seems to stem not so much from a belief that Birnbaum incorrectly stated the purpose for adoption of rule $10 \mathrm{~b}-5$ as it does from the conviction that the purchaser-seller requirement is not consonant with the expansive role section $10(\mathrm{~b})$ and rule $10 \mathrm{~b}-5$ have come to play in the present scheme of federal securities regulation. The Birnbaum doctrine precludes the possibility that federal $\mathrm{law}^{33}$ can be used to remedy certain types of fraudulent activities. $^{34}$ However, the possibility that victims of securities fraud

cert. denied, 399 U.S. 909 (1970); Dasho v. Susquehanna Corp., 380 F.2d 262 (7th Cir.), cert. denied, 389 U.S. 977 (1967).

30. 3 L. Loss 1469.

31. See, e.g., Lowenfels, The Demise of The Birnbaum Doctrine: A New Era for Rule 10b-5, 54 VA. L. REv. 268 (1968); Ruder, Current Developments in the Federal Law of Corporate Fiduciary Relations-Standing to Sue Under Rule 10b-5, 26 Bus. LaW. 1289, 1294-95, 1302-03 (1971); Comment, The Purchaser-Seller Rule: An Archaic Tool for Determining Standing Under Rule 10b-5, 56 GEo. L.J. 1177 (1968); 1967 DUKB L.J. 898, 901.

32. See, e.g., Brief for SEC as Amicus Curiae at 27-28, Manor Drug Stores v. Blue Chip Stamps, 492 F.2d 136 (9th Cir. 1973). Having concluded that the Birnbaum doctrine is incorrect because it improperly restricts the scope of rule $10 \mathrm{~b}-5$ and is inconsistent with recent Supreme Court cases, the SEC in its brief stated that

the narrow view of the purpose and coverage of Rule 10b-5 that was articulated in Birnbaum is demonstrably in error in light of the authorities and legislative history ..... The recent decision of the Supreme Court in Superintendent of Insurance [v. Bankers Life \& Cas. Co., 404 U.S. 6 (1971)], in particular, reflects a broad interpretation of Rule $10 \mathrm{~b}-5$ seemingly at odds with the restrictive view of Birnbaum .... Id. at 19.

33. Such a victim still has recourse to state law. Often, one who is kept out of the federal courts by the Birnbaum doctrine is able to bring a state claim based on common law fraud, misrepresentation, breach of fiduciary duty, intentional interference with contractual relations, or tort. Kellogg, The Inability to Obtain Analytical Precision Where Standing to Sue Under Rule 10-5 Is Involved, 20 BUfFalo L. REv. 93, 97 (1971). It is interesting to note that the unsuccessful plaintiffs in Birnbaum subsequently obtained relief under state law. See Perlman v. Feldmann, 219 F.2d 173 (2d Cir.), cert. denied, 349 U.S. 952 (1955). The Second Circuit imposed liability on the ground that Feldinann's knowledge that the buyers would utilize the entire steel output of tbe corporation rather than sell it at the market price was held to have imposed a duty on Feldmann to share the "premiun" he received with the other shareholders.

The fact that fraud victims can rely on state law has not assuaged the Birnbaum critics, because the real possibility still exists that a securities fraud victim kept out of federal court by the Birnbaum doctrine will either find no rehef in state courts or receive inadequate relief. Another danger involved in relying too heavily upon state law in this area was voiced by former Chairman of the SEC, Manual Cohen, who indicated that the "danger is the . . . possibility for lack of uniformity of the standards of corporate responsibility." Cohen, The Development of Rule 10b-5, 23 Bus. LAW. 593, 595 (1968).

34. These classes of cases would be those in which the fraud was not connected 
may be left without an effective remedy has been recognized by the courts and as a result the Birnbaum doctrine often is not applied rigidly; rather, judicially created exceptions to the doctrine liave developed which permit certain classes of persons who are neither purchasers nor sellers to bring actions under rule $10 \mathrm{~b}-5 .^{.35}$

to any transaction by the plaintiff. This would include cases involving the sale of control by the defendant to third parties, insiders' purchases from third parties, suits by shareholders brought in their individual capacities involving the sale of securities by the corporation to third parties, and cases involving only the breach of a fiduciary duty. See 1 A. BROMBERG § 4.7(562).

35. The first of these exceptions is that a plaintiff in a private suit seeking only an injunction does not have to show he was a purchaser or seller of securities. See, e.g., Vincent v. Moench, 473 F.2d 430, 434-35 (10th Cir. 1973); Kahan v. Rosenstiel, 424 F.2d 161, 173 (3d Cir. 1970); Mutual Shares Corp. v. Genesco, Inc., 384 F.2d 540, 546-47 (2d Cir. 1967). This exception follows from the general rule enunciated by the Supreme Court that in an action for equitable relief, the plaintiff does not have to prove all the elements necessary for obtaining relief in an action for money damages. SEC v. Capital Gains Research Bureau, Inc., 375 U.S. 180, 192-93 (1963). Since a major rationale for the purchaser-seller requirement is to shield defendants from huge liability, it is logical to relax the requirement where money damages are not involved. Further, since by its nature injunctive relief seeks to prevent injury, it would be unreasonable to make such remedies unavailable in rule $10 \mathrm{~b}-5$ cases until after a sale or purchase has occurred, the point at which the injury normally would occur.

Second, a plaintiff does not have to be a purchaser or seller when bringing a derivative suit; in this situation, the standing requirement is satisfied if the corporation on whose behalf the suit is brought bought or sold the securities. See, e.g., Rekant v. Desser, 425 F.2d 872, 877-78 (5th Cir. 1970); Shoenbaum v. Firstbrook, 405 F.2d 215, 219 (2d Cir. 1968), cert. denied, 395 U.S. 906 (1969); Ruckle v. Roto Am. Corp., 339 F.2d 24, 28 (2d Cir. 1964). See also 1 A. Bromberg $\$ 4.7(566)$. While a literal application of the Birnbaum doctrine might seem to preclude this result, these derivative suit cases actually are consistent with Birnbaum, since in a derivative action the plaintiff shareholder is not bringing a personal claim but rather is asserting a claim of the corporation in its behalf. See N. LatTin, The LAw of Corporations $\$ \$ 102-04$ (2d ed. 1971). Thus, it is necessarily the corporation and not the plaintiff shareholder who must meet the requirements of the Birnbaum doctrine.

Third, "forced sellers" may sue under section 10(b) and rule 10b-5 despite the ab. sence of an actual sale of securities. See, e.g., Dudley v. Southeastern Factor \& Fin. Corp., 446 F.2d 303, 307.08 (5th Cir.), cert. denied, 404 U.S. 858 (1971); Coffee v. Permian, 434 F.2d 383 (5th Cir. 1970); Crane Co. v. Westinghouse Air Brake Co., 419 F.2d 787 (2d Cir. 1969), cert. denied, 400 U.S. 822 (1970); Vine v. Beneficial Fin. Co., 374 F.2d 627 (2d Cir.), cert. denied, 389 U.S. 970 (1967). In these cases, where fraudulent activity has placed the victim in a position where he has no viable option except to sell his securities, he is a "forced seller" and courts have determined that "requiring him to do so [sell his security] seems a needless formality." Vine v. Beneficial Fin. Co., 374 F.2d 627, 634 (2d Cir. 1967). In Vine, a short-form merger was executed by defendant corporation. Plaintiff shareholder had held his stoek; however, he was placed in a situation where his only option was either to exchange his shares pursuant to defendant's offer or to exercise his right of appraisal. The Second Circuit held that the plaintiff was therefore a forced seller of stock and hence had standing to sue under section $10(\mathrm{~b}) . \quad I d$. at 635 .

The concept of "forced sale" was extended in Crane Co. v. Westinghouse Air Brake Co., 419 F.2d 787 (2d Cir. 1969). There, the Crane Company's tender offer 

baum doctrine, ${ }^{36}$ and although Supreme Court decisions interpreting rule $10 \mathrm{~b}-5$ have been rare, ${ }^{37}$ two recent cases ${ }^{38}$ dealing with section 10 (b) and rule $10 \mathrm{~b}-5$ shed considerable light on the Court's view of the role that these provisions should play in federal securities regulation. In marked contrast to the limited purposes of rule 10b-5 stated by Judge Hand in Birnbaum, both cases evidence an expansive reading of these provisions by the Court. Superintendent of Insurance $v$. Bankers Life \& Casualty $\mathrm{Co}^{39}$ reflects a liberal attitude toward section 10 (b) and rule $10 \mathrm{~b}-5$ and reveals a willingness to apply those provisions in situations where the purchaser-seller status of the plaintiff is at best subtle." ${ }^{40}$ The Supreme Court stated that "[s]ection 10(b) must be read flexibly, not technically and restrictively." 11 A year later, in Affiliated Ute Citizens $v$. United States, ${ }^{42}$ the Su-

36. In Superintendent of Ins. v. Bankers Life \& Cas. Co., 404 U.S. 6 (1971), the Supreme Court noted that the decision did not reach the question of the validity of the Birnbaum doctrine, since a sale of a security was found. Id. at 12. This was the first time the Supreme Court mentioned the Birnbaum requirement; one commentator estimated that prior to the Bankers Life decision, Birnbaum had been cited in 120 lower court cases. $1 \mathrm{~A}$. BRomberg $\S 4.7(522)$.

37. The first Supreme Court interpretation of rule 10b-5 did not come until 1969, in SEC v. National Sec., Inc., 393 U.S. 453 (1969).

38. Affibiated Ute Citizens v. United States, 406 U.S. 128 (1972); Superintendent of Ins. v. Bankers Life \& Cas. Co., 404 U.S. 6 (1971).

39. 404 U.S. 6 (1971). Bankers Life involved an alleged conspiracy in which the sole shareholder of Manhattan Casualty Company sold all his stock to a third party who immediately sold U.S. Treasury bonds owned by Manhattan and used the proceeds to purchase the stock, thus fimancing the purchase of Manhattan with Manhattan's assets. Suit was brought under section 10(b) and rule 10b-5 by New York's Superintendent of Insurance, representing Manhattan, who alleged that the transaction was a fraud upon the company. The Supreme Court held that the action was proper since the corporation itself was a seller of securities (its Treasury bonds) who could allege injury resulting from fraudulent practices.

40. In the sale of the stock in Bankers Life, both the purchaser and seller were parties to the fraud and therefore could not complam. Further, since the transaction imvolved all the stock of the company, there were no innocent shareholders to bring a derivative suit. Likewise with respect to the sale of the Treasury bonds, the fraud did not injure the buyer of the bonds and there were again no innocent shareholders to bring a derivative suit. Thus, Bankers Life presented the odd situation in which none of the direct participants in the transaction were injured by the fraud and all the former and present holders of equity interests in the corporation actually profited from the frand. The true injured parties, the creditors of the corporation, clearly did not have standing under rule $10 \mathrm{~b}-5$. The Court circumvented this problem by denominating the corporation itself as the injured party, despite the fact that all its shareholders had benefited from the fraud. Id. at 9-13.

41. Id. at 12 .

42. 406 U.S. 128 (1972). Under the Ute Partition Act, the Ute Indian Tribe distributed the assets of the tribe to its members by issuing shares of stock. The plaintiffs had sold these shares through the defendants, who had acted as market makers for the stock and had consistently purchased the stock from Indians at well below the 
preme Court, using language similar to that of Bankers Life, again read section $10(\mathrm{~b})$ broadly, ${ }^{43}$ providing a further indication that the Supreine Court currently views section 10(b) and rule 10b-5 expansively.

The Supreme Court's broad interpretation of section, 10(b) in Bankers Life contrasts so sharply with the tenor of Birnbaum that one district court, in Tully v. Mott Supermarkets, Inc., ${ }^{44}$ held that Birnbaum could no longer stand. While Tully involved an action for injunctive relief, and hence could fall within an exception to the purchaser-seller requirement, ${ }^{45}$ the Tully court instead chose to reject Birnbaum, stating that "[t]o imply . . . a [purchaser-seller] requirement ignores the recent edict by the Supreine Court [in Bankers Life] mandating a flexible as opposed to a technical or restrictive construction of [rule 10b-5]."46 Therefore, the Tully court indicated, "where there is a causal connection between the purchase or sale of stock, the alleged fraud or breach of fiduciary duty, and plaintiff's loss, then federal jurisdiction under 10b-5 exists." 47

The Supreme Court's liberal attitude towards section 10(b), plus the extent of the exceptions to the purchaser-seller requirement of Birnbaum, have caused uncertainty as to the current status of the purchaser-seller requirement. Several district courts have seemingly denied the continuing validity of the Birnbaum doctrine, ${ }^{48}$ and com-

price they obtained on resale. Plaintiffs brought an action under rule $10 \mathrm{~b}-5$ but the Tenth Circuit disallowed recovery since reliance by the plaintiffs on the non-disclosure causing the harm suffered had not been proved. The Supreme Court reversed, stating that under these circumstances, proof of the materiahty of the non-disclosure was sufficient for recovery. Id. at 153-54.

43. Id. at 151 .

44. 337 F. Supp. 834 (D.N.J. 1972).

45. See note 35 supra.

46. 337 F. Supp. at 839 . It is arguable, however, that Bankers Life actually reflects an unwillingness by the Supreme Court to dispense with the Birnbaum doctrine. The facts of the case did not present a clear instance of a defrauded seller or purchaser of securities, since any fraud in the sale of the stock involved both the seller and the purchaser, and in addition, there were no other shareholders to complain of the later sale of Treasury bonds. See note 40 supra. However, the Court chose to avoid the question of the validity of the purchaser-seller requirement by searching for a sale, rather than first rejecting Birnbaum and thus making the existence of a sale irrelevant.

47. 337 F. Supp. at 842.

48. In Neuman v. Electronic Specialty Co., [1969-1970 Transfer Binder] CCH FED. SEC. L. REP. If 92,591 (N.D. Ill. 1969), the court, while noting that the lack of a purchase or sale normally precludes an action for damages, allowed standing because the clear reliance of the plaintiff made causation and damages easily provable. The case would appear clearly to reject Birnbaum (since the claim was based on a nonacceptance of a tender offer and there was no sale), except for the fact that the court 
mentators have gone so far as to announce, albeit prematurely, the demise of the purchaser-seller requirement. ${ }^{49}$ Yet, while the strict requirement stated by Birnbaum has been eroded, until Eason all the circuits continued to adhere generally to the doctrine, at least in actions for damages. ${ }^{50}$ While courts have seemed adept at avoidimg the purchaser-seller requirement where particularly unfair results would be caused by its application, ${ }^{51}$ there has been a marked un-

stated in the midst of the opinion that "plaintiffs can . . . be regarded as actual sellers of securities." Id. at 98,705. In Nanfito v. Tekseed Hybrid Co., 341 F. Supp. 234 (D. Neb. 1972), the district court, acting on a motion for summary judgment, stated that the plaintiffs were neither purchasers nor sellers and yet allowed standing. The court ruled that a sale or purchase was not necessary as long as section $10(\mathrm{~b})$ was violated and the plaintiff's stock decreased in value as a result. Id. at 238 . In the decision on the merits, Nanfito v. Tekseed Hybrid Co., 341 F. Supp. 240 (D. Neb. 1972), however, the district court stated there was a sale and purchase since there was a merger. Id. at 243. On appeal, the Eighth Circuit stated in a footnote that standing was proper, but cited a forced seller case. 473 F.2d 537, 541 n.6 (8th Cir. 1973). In Entel v. Allen, 270 F. Supp. 60 (S.D.N.Y. 1967), the court stated that the forced seller and aborted seller-purchaser cases came close to overnuling Birnbaum, if they did not in fact do so. Id. at 69.

49. See, e.g., Lowenfels, supra note 31. It is perhaps well to remember the cautionary words of Professor Loss that the pronouncements of the death of Birnbaum "evoke meinories of Mark Twain." 6 L. Loss 3620 (Supp. 1969).

50. See note 29 supra. Recently the Third Circuit, while noting that the Birnbaum doctrine has undergone some erosion, stated that "[b]uyer or seller status is indispensable in establishing liability for damages under rule 10b-5." Landy v. FDIC, 486 F.2d 139 (3d Cir. 1973), cert. denied, 42 U.S.L.W. 3593 (U.S. Apr. 22, 1974). Since Eason was decided, the Fifth Circuit has stated: "To eliminate any doubt, we expressly reaffirm the vitality of the purchaser-seller requirement in this circuit." Sargent v. Genesco, Inc., 42 U.S.L.W. 2552, 2553 (5th Cir. Apr. 11, 1974).

51. Courts may circumvent the purchaser-seller requirement by employing one of its several exceptions. See note 35 supra. If none is available, courts may still allow standing by broadly defining sale and purchase. For example, in International Controls Corp. v. Vesco, CCH Fed. Sec. L. Rep. II 94,356 (2d Cir. Jan. 15, 1974), the plaintiff corporation asserted that certain of defendant's actions violated rule $10 \mathrm{~b}-5$. To meet the purchaser-seller requirement, plaintiff argued that a dividend it had paid to its shareholders consisting of portfolio securities was a sale of securities. This assertion ran counter, however, to Show v. Dreyfus, 172 F.2d 140 (2d Cir.), cert denied, 337 U.S. 907 (1949), which had held that purchase and sale for the purposes of the Exchange Act meant acquisition or disposition for consideration. Id. at 142 . Although clearly no consideration was given for the dividend of portfolio securities the International Controls court held that the dividend constituted a sale for purposes of Birnbaum. The court stated that "although in other contexts the term 'sale' might appropriately be construed more narrowly, we find a rote emphasis on consideration inconsistent with the broad scope of protection under 10(b) ..." CCH FED. SEc. L. REP. If 94,356, at 95,196. See also Cambridge Capital Corp. v. Northwestern Nat'1 Bank, 350 F. Supp. 829 (D. Minn. 1972), where it was held that a plaintiff who had a security interest in securities sold at a sheriff's sale was a "seller of securities."

Even when no exceptions are available and the case does not lend itself to application of a broad definition of purchase and sale, a court may still allow suit to be brought. In Manor Drug Stores v. Blue Chip Stamps, 492 F.2d 136 (9th Cir. 1973), 
willingness to abrogate the requirement generally. Thus, the Birnbaum doctrine has remained a major stumbling block on the road to rule $10 \mathrm{~b}-5$ recovery. ${ }^{52}$

Against this background, the Seventh Circuit faced the issues presented by Eason v. General Motors Acceptance Corp..$^{53}$ and unequivocally declared that the Birnbaum doctrine "is not part of the law of this circuit." J4 Judge Stevens began by rejecting the plaintiffs' suggestion that they were "sellers" (or "purchasers") of a security. ${ }^{55}$ Rather, he indicated that the issue presented was the continuing validity of the Birnbaum doctrine:

The question which is thus presented is whether, notwithstanding the fact that they were neither purchasers nor sellers of a security, plaintiffs may obtain rehef under Rule $10 \mathrm{~b}-5 .{ }^{\mathrm{bc}}$

Assuming that all other jurisdictional requirements had been adequately alleged, ${ }^{57}$ the court analyzed the Birnbaum doctrine itself. Initially, the court criticized the frequent references to the purchaserseller limitation as a "standing requirement," indicating that the question before the court was not one of constitutional standing, ${ }^{58}$ but rather was whether the plaintiffs were members of the class which rule $10 \mathrm{~b}-5$ was designed to protect. The court noted that rule $10 \mathrm{~b}-5$

plaintiffs had been entitled under an antitrust consent decree to purchase a fixed amount of defendant corporation's stock at a discount. Due to defendant's alleged fraud, plaintiffs were discouraged from purchasing, and sued under rule 10b-5. The Ninth Circuit allowed standing, stating that the consent decree was the "functional equivalent" of a contract which made causation and damages capable of proof, which in turn satisfied the demands of the Birnbaum doctrine. For authority, the court cited aborted purchaser-seller cases. Those cases, however, are not based on the degree of speculativeness of damages but on the statutory definition of sale and purchase. See note 35 supra. Since in Manor Drug there clearly was no sale, broad definitions could not be used to circumvent the purchaser-seller requirement. Still, the court allowed standing.

52. As Judge Wisdoin has commented: "Bloody but unbowed, Birnbaum still stands." Rekant v. Desser, 425 F.2d 872, 877 (5th Cir. 1970).

53. 490 F.2d 654 (7th Cir. 1973), cert. denied, 42 U.S.L.W. 3609 (U.S. Apr. 22, 1974). See notes 1-6 supra and accompanying text.

54. Id. at 661.

55. Plaintiffs had argued that the guarantees themselves were securities sold to GMAC, that the underlying notes were securities they had been forced to purchase, and that they were indirect sellers of the 7,000 shares of stock. Id. at 656 .

56. $1 d$.

57. It is interesting to note that the court stated that Bank Service clearly could have brought suit. Id. Therefore, the plaintiffs could have avoided the purchaserseller issue by bringing a derivative action. See note 35 supra. Choosing to bring suit on the guarantees they had given in their personal capacities, however, foreclosed this result.

58. A party bringing an actiou must always show a personal stake in the controversy he seeks to have adjudicated. See note 4 supra and accompanying text. 
had been extended to cover many types of misconduct and had been interpreted to extend protection to persons not within the purview of the traditional definition of purchaser or seller; and additionally, the Supreine Court had commanded that rule 10b-5 should be read flexibly and broadly. ${ }^{59}$ While acknowledging that no Supreme Court decision could be read as rejecting the Birnbaum doctrine, the court stated that recent Supreme Court rulings implied that the purchaser-seller requirement too narrowly restricted the proper scope of rule $10 \mathrm{~b}-5 . .^{00}$ The Eason court then held that the rule properly extends coverage to all persons who, in their capacity as investors, suffer significant injury as a direct consequence of fraud in connection with a securities transaction, even though their participation in the transaction did not involve either the purchase or the sale of a security. ${ }^{61}$

Responding to the contention that rejection of Birnbaum would result in a flood of federal litigation and inconsistency in the interpretation of federal securities law, the court indicated that these results were outweighed by the importance of giving proper effect to rule $10 b-5 .^{62}$ However, the court refused to attempt to formulate a new standard, trusting instead "that the appropriate limits to the rule will best be defined through the process of case by case adjudication."

The essence of the controversy surrounding the Birnbaum doctrine is the question of who may invoke the protection of section 10(b) and rule 10b-5. In 1952, the Second Circuit in Birnbaum declared that only purchasers and sellers should be so protected. The fact that over twenty years elapsed and hundreds of cases were decided before even one circuit court unequivocally rejected this formulation of the scope of rule $10 \mathrm{~b}-5$ seems to reflect a belief that some limitation upon the class of persons protected by rule $10 \mathrm{~b}-5$ is necessary ${ }^{64}$ On the other hand, the number of exceptions which have arisen and the somewhat flexible manner in which the rule has been applied seem to manifest a countervailing belief that the purchaser-seller requirement is not a completely acceptable delineation of the proper scope of section, 10(b) and rule 10b-5. Whatever the wisdom of

59. 490 F.2d at 658-59. See notes 38-43 supra and accompanying text.

60. Id. at 659 .

61. Id.

62. Id. at $660-61$.

63. Id. at 660 .

64. The importance of the Birnbaum doctrine as a limitation on the number of potential plaintiffs and the magnitude of 10b-5 damages liability has often been recognized and commented upon. See, e.g., Rekant v. Desser, 425 F.2d 872, 877 (5th Cir. 1970); Lowenfels, supra note 31, at 269-71; Ruder, supra note 31, at 1294-95; Comment, supra note 31 , at $1178-79$. 
the substance of the Eason courts holding, one must commend its decision, when faced with a plaintiff who seemed deserving of rule $10 \mathrm{~b}-5$ protection yet who was neither a purchaser nor seller, to analyze the validity of the Birnbaum doctrine ${ }^{65}$ rather than to follow the now common praatice of avoiding the effects of the purchaserseller requirement either by utilizing an exception thereto or by defining purchaser or seller broadly.

When one does examine the substance of the Eason court's decision, its conclusion that the purchaser-seller requirement is a faulty and improper delineation of the scope of coverage of rule $10 \mathrm{~b}-5$ is difficult to criticize. The limitation imposed by Birnbaum was determined with reference to the purpose which rule $10 \mathrm{~b}-5$ was meant to have when promulgated by the SEC in $1942 .^{68}$ Since Birnbaum was decided, however, the application of rule $10 \mathrm{~b}-5$ has expanded spectacularly. ${ }^{67}$ Thus the present question should be not so much whether the purchaser-seller requirement is consonant with the original purpose of rule 10b-5, but whether it is compatible with the exceedingly widespread role that rule $10 \mathrm{~b}-5$ has come to play in modern federal securities regulation. The Birnbaum requirement seems at odds not only with rule $10 \mathrm{~b}-5$ 's current usage but also with the Supreme Court's liberal reading of the rule. ${ }^{88}$ Further, the purchaser-seller requirement has been largely robbed of its internal logic by the exceptions which have developed to the doctrine and by the use of broad definitions of "purchase" and "sale." 69 When the fact that the requirement is at times seemingly applied in an arbitrary fashion $^{70}$ is added to these criticisms, it becomes difficult to criticize

65. The court's conclusion that the issue involved is the coverage of the rule rather than constitutional standing is sound. In these cases, the plaintiffs clearly have a direct injury as required for constitutional standing. See note 4 supra. Further, Birnbaum itself was based upon a conclusion as to the proper scope of rule 10b-5, rather than the issue of constitutional standing. See notes 25-26 supra and accompanying text.

66. See notes 25-26 supra and accompanying text.

67. See notes 20-21 supra and accompanying text.

68. See notes 39-43 supra and accompanying text.

69. The Seventh Circuit in Eason noted that the purchaser-seller requirement does not "have integrity when the words 'purchaser' and 'seller' are construed as flexibly as has been necessary in order both to decide $10 \mathrm{~b}-5$ cases properly and also to continue to pay homage to the Birnbaum rule." 490 F.2d at 659 .

70. A court may circumvent the purchaser-seller requirement in one case yet apply it in another quite similar case. Compare Mount Clemens Indus., Inc. v. Bell, 464 F.2d 339 (9th Cir. 1972), with Manor Drug Stores v. Blue Chip Stamps, 492 F.2d 136 (9th Cir. 1973). The plaintiff in each of these cases was fraudulently prevented from buying securities at a legally required sale. In Mount Clemens the plaintiff was thwarted from purchasing securities at a sheriff's sale, 464 F.2d at 340; in Manor Drug, the plaintiff was fraudulently dissuaded from purchasing securities required to be of- 
a court which takes the forthright step of rejecting the Birnbaum doctrine.

The Eason court's decision may be faulted, however, for failing to consider the formulation of a substitute limiting standard. The court indicated two policy justifications for continued adherence to the purchaser-seller requirement: limiting the federal judiciary's workload and promoting consistency in the interpretation of federal securities laws. However, there is at least one additional justification for the requirement that should have been recognized and considered: the purchaser-seller requirement is a limiting doctrine, which, by restricting the number of plaintiffs who can successfully bring suits under rule 10b-5, serves to limit the total potential liability of any in. dividual or corporation. ${ }^{71}$

The problem of "draconian damage claims"72 under rule 10b-5 has become one of increasing concern. ${ }^{73}$ Recent cases have imposed on defendant corporations liability far exceeding their net worth. ${ }^{74}$ While the various elements necessary for rule $10 \mathrm{~b}-5$ recov-

fered to him under an antitrust consent decree. 492 F.2d at 138-40. In Mount Clemens, standing was not allowed, 464 F.2d at 341-47, while in Manor Drug the case was permitted to go to trial, 492 F.2d at 140-42. Compare Neuman v. Electronic Specialty Co., [1969-1970 Transfer Binder] CCH FED. SEC. L. REP. II 92,591 (N.D. Ill. 1969), with Iroquois Indus., Inc. v. Syracuse China Corp., 417 F.2d 963 (2d Cir. 1969), cert. denied, 399 U.S. 909 (1970). Both cases involved tender offers. In Netlman, plaintiffs did not accept a tender offer due to defendant's alleged fraud, $\mathbb{9 2 , 9 5 1}$ at 98,702 ; in Iroquois, plaintiff's tender offer was thwarted by defendant's alleged fraud, 417 F.2d at 966 . Therefore, neither case involved the purchase or sale of a security. However, standing was allowed in Iroquois and not in Neuman. See also Ruder, supra note 31, at 1294-95 \& n.35.

71. See note 64 supra and accompanying text.

72. Manor Drug Stores v. Blue Chip Stamps, 492 F.2d 136, 147 (9th Cir. 1973) (dissenting opinion).

73. See, e.g., Bradford, Rule 10b-5: The Search for a Limiting Doctrine, 19 BurFalo L. REv. 205 (1970); Ruder, Texas Gulf Sulphur-The Second Round: Privity and State of Mind in Rule 10b-5 Purchase and Sales Cases, 63 Nw. U.L. Rev. 423 (1968); Note, The Role of Scienter and the Need to Limit Damages in Rule 10b-5 Actions-The Texas Gulf Sulphur Litigation, 59 KY. L.J. 891 (1971).

74. Note, for example, the Texas Gulf Sulphur litigation. The facts of the Texas Gulf Sulphur (TGS) cases are as follows: TGS made an incredibly rich strike of ore in Canada, which had become apparent by November 12, 1963, when the first test drilling was completed. For a period of five months the results of this and other tests were withheld from the public, but, during this same period insiders, aware of the discovery, purchased TGS stock and calls. On April 12, 1964, TGS issued a somewhat pessimistic press release intended to quash rumors about the strike. It was not until April 16, 1964, that TGS made an official public announcement revealing the true nature of the discovery. These events resulted in suits brought under rule $10 \mathrm{~b}-5$, based alternatively on either non-disclosure of material facts from November 12th to April 16th or on plaintiffs' reliance on the misleading press release. See SEC v. Texas Gulf Sulphur Co., 401 F.2d 833, 843-47 (2d Cir. 1968), cert. denied, 394 U.S. 976 (1969). 
ery remain uncertain, ${ }^{75}$ it seems clear that during the last ten years, the requirements have become less stringent. As a result the possibility of crushing liability under rule $10 \mathrm{~b}-5$ has become imcreasingly real. Rejection of the purchaser-seller requirement, by allowing a greater number of plaintiffs to succeed in rule $10 \mathrm{~b}-5$ suits, or at least to overcome preliminary motions to dismiss, ${ }^{76}$ merely exacerbates

The amount of TGS's potential liability resulting from these cases was tremendous. Professor Ruder estimates that tf recission were used as the measure of damages (including loss of future profits which would have been made) aud relief given from November 12th to April 16th, damages would have amounted to over $\$ 390,000,000$; this sum would have been $\$ 150,000,000$ more than TGS's net worth. Ruder, supra note 73, at 428-29. Another writer calculates that if the Utah District Court's formula of damages in Reynolds v. Texas Gulf Sulphur Co., 309 F. Supp. 548 (D. Utah 1970), aff'd in part and rev'd in part sub nom., Mitclell v. Texas Gulf Sulpliur Co., 446 F.2d 90 (10th Cir. 1971), cert. denied, 405 U.S. 918 (1972) (based on the value the stock reached during a reasonable period after the full announcement), were to be multiplied by the number of shares traded during the eleven trading days following the April 12th press release, damages for that period alone would equal $\$ 30,978,554-$ or about $23 \%$ of total shareholder equity. Note, supra note 73, at 909-10. Eighty-one New York cases were settled for $\$ 2,700,000$; TGS has deposited this amount in escrow in two funds. In the first, $\$ 2,200,000$ was set aside for claims based on reliance upon the press release; $\$ 500,000$ was placed in the second fund for claims based on non-disclosure during testing. Cannon v. Texas Gulf Sulphur Co., 55 F.R.D. 308, 310-11 (S.D.N.Y. 1972).

75. It has become quite difficult to discern the status of each of the various elements needed for rule $10 \mathrm{~b}-5$ recovery. For example, it was once rather uniformly thought that reliance by plaintiffs on the alleged fraud was a prerequisite to recovery in rule $10 \mathrm{~b}-5$ cases. However, in Affiliated Ute Citizens v. United States, 406 U.S. 128 (1972), the Supreme Court lield that, in that particular case, proof of reliance was not necessary for recovery. Id. at 152-54. At least one court has interpreted $U$ te as holding that when materiality is slown, proof of reliance is not needed. In re Penn Cent. Sec. Litigation, 347 F. Supp. 1327, 1344 (E.D. Pa. 1972), modified in part, 357 F. Supp. 860 (E.D. Pa. 1973). Likewise, scienter on the part of the defendants was at one time considered a necessary rule $10 \mathrm{~b}-5$ element. Today there is considerable controversy over whether a slowing of mere negligence is sufficient. Compare Myzel v. Fields, 386 F.2d 718, 734-35 (8th Cir. 1967) ("Proof of 'scienter' . . is not required under Section 10(b)"), with Shemtob v. Shearson, Hammil \& Co., 448 F.2d 442, 445 (2d Cir. 1971) ("It is insufficient to allege mere negligence"), and White v. Abrams, CCH Fed. Sec. L. REp. II 94,457 (9th Cir. Mar. 15, 1974). Professor Loss has indicated a reason for the uncertainty as to what elements are required in a private cause of action under 10b-5:

Since Congress could have given no thought to civil liability under $10(\mathrm{~b})$, ob-

viously it could provide no compreliensive scheme with respect to the basic elements of a private right of action under the then inconceived Rule 10b-5 - the extent of an affirmative obligation to speak, materiality, reliance, scienter, causation, privity, or measure of damages. Loss, Reporter's Introductory Memorandum, in Ali Federal Securities Code xvii (Tent. Draft No. 2, 1973).

The trend in general has been from strict to more lax standards. For an excellent discussion of the various elements necessary for rule $10 \mathrm{~b}-5$ recovery, see Note, SEC Rule 10b-5: A Recent Profile, 13 WM. \& MARY L. REv. 860 (1972).

76. This is particularly important given the prochivity of defendants in rule $10 \mathrm{~b}-5$ 
the problem. ${ }^{77}$

The potential for increased liability resulting from a rejection of the purchaser-seller requirement does not inean, however, that the Seventh Circuit erred in rejecting the Birnbaum doctrine. This consideration does not affect the validity of the reasons discussed above which demonstrate that Birnbaum is out of harmony with rule $10 \mathrm{~b}-5$ 's present role in federal securities regulation. ${ }^{78}$ Further, even if some limitation is needed to confine the potentially vast liability of defendants in rule $10 \mathrm{~b}-5$ cases, the purchaser-seller requirement has proved to be an inefficient limiting device in that it may allow dracoman damage claims in some cases ${ }^{79}$ while totally prohibiting recovery in other cases where there exists a definite ceiling on the defendant's potential liability. ${ }^{80}$ Thus it would seem that the most satisfactory approach to the problem would be to abrogate Birnbaum and erect in its place a new and more effective limitation on damages.

While equity would seem to demand that all those injured by fraud in a securities transaction, including non-purchaser-sellers, be afforded some form of relief, several deleterious effects would result from a rejection of the Birnbaum doctrine unaccompanied by a new limiting standard. The elimination of the purchaser-seller requirenent will import into the arena of rule $10 \mathrm{~b}-5$ a new class of plaintiffs with respect to whom it will be more difficult than ever for the courts to arrive at an assessment of the damages actually incurred. The reason for this is that in those cases where the plaintiff himself neither purchased nor sold the security in question, whether he suffered any harm as a result of the defendant's fraudulent conduct and,

cases to settle the case once the complaint survives preliminary motions to dismiss. See 6 L. Loss 3579 (Supp. 1969).

77. Note the increase in potential liability that a rejection of the purchaser-seller requirement would have in a situation like that of Texas Gulf Sulphur. The corporation would be liable not only to shareholders who had sold the stock during the period between publication of the fraudulent press release and announceinent of the true nature of affairs, but it would also conceivably be liable to all people who would have bought the stock during that period if all the facts had been revealed as soon as they were known. Adinittedly, such persons would find it more difficult to prove their case than would the selling shareholders; still, it is unlikely that this would present an insurmountable obstacle to recovery in every case. Further, if such persons were able to survive a preliminary motion to dismiss, settleinent would become likely. See note 76 supra.

78. See notes 66-70 supra and accompanying text.

79. For example, the Birnbaum doctrine did not prevent huge liabilities in the Texas Gulf Sulphur litigation. See note 74 supra.

80. Eason is an excellent illustration: it was a case with fixed aud limited liability-the $\$ 300,000$ loss to be borne either by the plaintiffs or GMAC. Still, a strict application of the Birnbaum doctrine would not have allowed such a case to go to trial. 
if so, the magnitude of that harm will be exceedingly difficult to demonstrate. ${ }^{81}$ This difficulty might in turn greatly complicate any class action to which such plaintiffs are parties, ${ }^{82}$ a matter of particular interest given the importance that class actions have had in rule 10b-5 cases. ${ }^{83}$ Furthermore, class action participation by such plaintiffs could result in a lessening of the standard of proof necessary for recovery; indeed, it has been noted that the effect of class actions on rule $10 \mathrm{~b}-5$ cases has been "to restrict the operation of any element that would frustrate commonality and fragment or prevent recovery by the class." 84 In any event, difficulties of proof would not thwart all non-purchaser-seller plaintiffs, ${ }^{85}$ and the likelihood of huge dainage claims would thus be increased. Further, even if many such plaintiffs would be unable ultimately to succeed on the merits, inany

81. The Ninth Circuit has recently observed that the primary justificatiou for imposition of the purchaser-seller requirement is the problem of proof in cases brought by non-purchaser-sellers: "Ordinarily there will be little proof (other than the non-purchaser's own opinion, after the loss) that the non-purchaser would in fact have purchased but for the fraud, and, if so, how much, when, or at what price . . ." Manor Drug Stores v. Blue Chip Stamps, 492 F.2d 136, 141 (9th Cir. 1973). See also Boone \& McGowan, Standing to Sue Under SEC Rule 10b-5, 49 Tex. L. REv. 617, 647-48 (1971); Kellogg, supra note 33, at 96-97.

82. The Federal Rules of Civil Procedure require as a prerequisite for any class action that "the questions of law or fact common to the members of the class predominate." Fed. R. Civ. P. 23(b)(3). See also Note, Class Action Treatment of Securities Fraud Suits Under the Revised Rule 23, 36 GEO. WaSH. L. REv. 1150, 1153-54 (1968). Defendants would more than likely argue that with regard to the non-purchaser-seller plaintiffs as to whom such questions of causation and damages existed, commonality did not exist. If this argument were accepted, destruction of the class might result.

83. One court has written:

If, as here, the security in connection with which the alleged misrepresentations and violations of $10 \mathrm{~b}-5$ have been made is publicly held, a class action may well be the appropriate means for expeditious hitigation of the issues, because a large number of individuals may have been mjured, although no one person may have been damaged to a degree which would have induced him to institute litigation solely on his own behalf. Green v. Wolf Corp., 406 F.2d 291, 296 (2d Cir. 1968), cert. denied, 395 U.S. 977 (1969).

For further discussions of the benefits derived from the use of the class action in securities litigation, see Esplin v. Hirschi, 402 F.2d 94, 100-01 (10th Cir. 1968), cert. denied, 394 U.S. 928 (1969); Escott v. Barchris Constr. Corp., 340 F.2d 731, 733 (2d Cir.), cert. denied, 382 U.S. 816 (1966); 3 L. Loss 1819-24; Comment, The Impact of Class Actions on Rule 10b-5, 38 U. CHI. L. REv. 337, 365-71 (1971).

84. Comment, supra note 83, at 345. For a case-by-case analysis of the effect class actions have had upon rule 10b-5, see id. at 341-65. See also Note, Federal Rules of Civil Procedure: Rule 23, The Class Action Device and 1ts Utilization, 22 U. FLA. L. REV, 631, 643-45 (1970).

85. Given the willingness sliown by the courts during the last decade to lessen the stringency of the various elements necessary for rule 10b-5 rehief, see note 75 supra and accompanying text, the problein of proof of causation and damages could conceivably prove to be less difficult than one would at first assume. 
could survive a preliminary motion to dismiss and would therefore be able to participate in settlements in $10 \mathrm{~b}-5$ cases, which as noted above are frequent. ${ }^{86}$

The formulation of a new limitation on liability would also be important for several additional reasons. First, there is little logic in submitting a corporation to liability in excess of its net worth or an mdividual to liability in excess of an amount he conceivably can pay -both of which could frequently occur in the absence of a limiting doctrine. It is difficult to find in the securities laws a policy which justifies placing corporations and their insiders under the threat of bankruptcy. Deterrence of fraudulent activity would seem to require less than the huge potential liability present in many cases today. Nor can it be argued that the benefits of full compensation to victims justify such a result; manifestly, once liability exceeds the amount which a defendant can pay, full recovery becomes illusory. It may be argued that the defendant caused the harm and therefore the plaintiff ought to be fully compensated regardless of the resultant harm to the defendant, as is the theory in tort or contract. ${ }^{87}$ However, it is arguable that recovery under rule $10 \mathrm{~b}-5$ is reaching a point exceeding mere compensation; that is, cases have been decided in which the plaintiff's recovery seems even to have exceeded the damages suffered. ${ }^{88}$ As

86. See note 76 supra.

87. See 5 A. Corbin, Corbin on Contracrs $\$ 992$ (1964); W. Prosser, HandBOOK OF THE LAW OF TORTS $\S 1$, at 6 (4th ed. 1971).

88. See, e.g., Rochez Bros., Inc., v. Rhoades, 353 F. Supp. 795 (W.D. Pa.), vacated and remanded, CCH FeD. SEc. L. ReP. If 94,339 (3d Cir. 1973). In Rochez, the plaintiff corporation and the defendant were both 50 percent shareholders of M.S. \& R., Inc., defendant was president and plaintiff's president was vice president. Because of dissension between them, they found it difficult to run the business. Finally, a buysell agreement between them was agreed upon; plaintiff agreed to sell its shares to defendant for $\$ 598,000$, and the sale took place in November, 1967. The defendant did not inform the plaintiff that two parties had previously expressed interest in purchasing the business; at any rate, both of these parties determined not to purchase. Subsequently, in July 1968, defendant did sell out to Esterline Corporation, which had expressed no interest in the business until five months after plaintiff had sold his interest. Defendant received as consideration $\$ 4,250,000$ in cash plus 50,000 shares of Esterline restricted stock. Id. at 799-801. Even though the plaintiff as vice president was in a position of knowing completely about the inside workings of the company, and his financial expertise was superior to that of the defendant, he alleged that defendant's failure to disclose that other parties had expressed some interest in purchasing the business constituted a violation of rule $10 \mathrm{~b}-5$. The trial court admitted that "[w]hen plaintiff sold its half, it was not worth much if anything more than what plaintiff received for it." Id. at 804. Further, the court recognized that the increase in price paid by Esterline was largely the result of the managerial efforts of the defendant after the plaintiff sold out. Id. at 803 . Nevertheless the court beld the defendant liable under rule 10b-5 for non-disclosure of the interest shown by the two potential buyers; damages were calculated at $\$ 402,000$. Id. at $805-06$. On appeal, the Third Circuit agreed 
the reach of rule $10 \mathrm{~b}-5$ becomes wider, it becomes efficacious to consider the effect such recovery has upon the defendant. It is important to note that the ultimate burden of liability under rule $10 \mathrm{~b}-5$ often rests on the defendant corporation's shareholders, who paradoxically are "usually the most important segment of the total category of investors intended to be protected." 89 For example, if the corporation is stung with a large judgment, it is the shareholders who are hurt. $^{90}$ If a judgment is obtamed against an officer or director, the possibility exists that the corporation will indemnify him, ${ }^{91}$ thus

that the defendant had violated rule 10b-5; however, it found the damage award to be erroneous. Despite the trial court's finding that most of the increase in price of the stock resulted from the personal efforts of the defendant, the court of appeals determined that the damages were 50 percent of the consideration given by Esterline, minus the purchase price received by plaintiff. CCH FED. SEC. L. REP. II 94,339, at 95,151. This figure was approximately $\$ 2,000,000$. If this is compensation, then it is compensation with a vengeance.

Negligent non-disclosure by a corporation of a material fact concerning the corporation in the absence of any trading by the corporation or its insiders presents another situation in which the recovery at times appears to exceed the amount of harm resulting to the plaintiff. See note 90 infra. If the non-disclosure lasts for any length of time and there is active trading in the corporation's stock, the total hability will add up to a tremendous figure. Yet the plaintiffs were not injured by the presence in the market of traders with superior knowledge. In such a case, parity of information was present anong all traders; the problem lay in the fact that everyone trading had insufficient information. When the loss experienced by the plaintiff is caused in this manner, it is harder to justify the huge damage clains against the corporation than when the corporation or its insiders have been in the market reaping profits on the basis of inside information. In such situations, full recovery of all losses of all plaintiffs would seen to place upon the corporation a greater onus than its action or maction ments.

In considering whether rule $10 \mathrm{~b}-5$ has gone beyond compensation, not only the damage awards but also the settlement rate should be considered. There is a marked tendency for defendants to settle $10 \mathrm{~b}-5$ cases if the plaintiffs survive prehiminary motions to dismiss. See note 76 supra. This settlement rate is caused no doubt by the potential for huge damage awards and the general uncertainty as to the elements necessary for recovery. As the requirements for rule $10 \mathrm{~b}-5$ recovery become less stringent, see note 75 supra and aceompanying text, it becomes easier for plaintiffs to survive such motions, and therefore, it may be expected that rule 10b-5 settlements increasingly will include not only plaintiffs who clearly have been injured by defendant's fraud, but also plaintiffs whose injury is doubtful at best.

89. Cohen, "Truth in Securities" Revisited, 79 HaRv. L. Rev. 1340, 1370 (1966).

Judge Moore, dissenting in SEC v. Texas Gulf Sulphur Co., 401 F.2d 833 (2d Cir. 1968), cert. denied, 394 U.S. 976 (1969), while criticizing the imposition of liability resulting from a corporate press release, commented:

And finally there is the sardonic anoinaly that the very members of society which Congress has charged the SEC with protecting, i.e., the stockholders, will be the real victims of its misdirected zeal. Id. at 889 .

90. It has also been suggested that a part of a defendant corporation's damage payments may in some instances be passed on to the customers of the corporation. ISee Comment, Liability Under Rule 10b-5 for Negligently Misleading Corporate Releases: A Proposal for the Apportionment of Losses, 122 U. PA. L. REv. 162, 168 (1973).

91. Indemnification of officers and directors is provided for in two states which 
draining funds from the corporation and injuring its shareholders. Even if no action is ever brought against the corporation or its officers or directors, the risk of huge dainage claims may impel the corporation's purchase of insurance for its officers and directors. ${ }^{92}$ Once again, the cost is ultimately borne by the corporation's shareholders. Even when indemnification by the corporation or insurance purchased by the corporation is not employed, the shareholders inay nonetheless be injured if the threat of huge liability causes competent outsiders to refuse to accept directorships. ${ }^{93}$ It may be argued, however, that such costs ought to be borne by shareholders who are owners and ultimate controllers of the corporation. While this argument may have validity in the case of a closely-held corporation where corporate action is directed or at least closely monitored by the shareholders, it has little force in the case of a large public-issue corporation whose shareholders are almost all passive investors who take no real part in the management of the corporation. Especially in those areas just beginning to be reached by rule $10 \mathrm{~b}-5$, the equities between plaintiffs and passive shareholders become difficult to balance. ${ }^{94}$ In

have a large amount of corporate litigation, New York and Delaware. See Del. CoDE ANN. tit. 8, § 145 (Cum. Supp. 1970); N.Y. Bus. CoRP. LAW \$\$ 722-26 (McKinney 1963), as amended, (McKinney Supp. 1973-74). For an extensive discussion of indemnification of corporate officers and directors, and a compilation of state statutes dealing with indemnification, see G. WASHINGTON \& J. Bishop, INDEMNIFYing THE CORPORATE EXECUTIVE (1963).

92. California and New York have recently enacted provisions providing for insurance to indemnify corporate officers and directors. See CAL. Corp. Code ANN. \& 830(h) (West Supp. 1974); N.Y. Bus. CoRP. LAw $\$ 727$ (McKinney Supp. 1973-74). See generally Bishop, New Cure for an Old Ailment: Insurance Against Directors' and Officers' Liability, 22 Bus. LAw. 92 (1966); Note, Public Policy and Directors' Liability Insurance, 67 ColUM. L. REv. 716 (1967); Note, Liability Insurance for Corporate Executives, 80 HARV. L. REv. 648 (1967).

93. It may be asserted that the widespread threat of rule $10 \mathrm{~b}-5$ hability might compel corporations to select their directors more carefully, hence benefiting the shareholders. This argument breaks down, however, if the size of potential liabilities is so great as to make directorsbips worthwhile only to those who are significantly benefited by holding them (e.g., insiders).

For discussions of the potential liability of corporate officers and directors, see $\mathbf{G}$. WASHINGTON \& J. BishoP, supra note 91, at 1-5; Anderson, Directors and Officers Liability Insurance, 47 CHI. B. REC. 31 (1965); Note, Liability Insurance for Corporate Executives, supra note 92.

94. Take the situation, for example, where a corporation negligently fails to disclose the existence of a new product which will substantially increase the value of the corporation's stock; however, during the period of non-disclosure, neither the corporation nor its insiders purchase or sell any stock. Professor Loss states that such cases should not result in recovery. See 6 L Loss 3597 (Supp. 1969). However, Professor Marsh states that such a decision would be within the current scope of rule 10b-5 as interpreted by various cases. Marsh, What Lies Ahead Under Rule 10b-5?, 24 Bus. 
light of the exacerbating effect which abolition of the purchaser-seller requirement will have on these problems, it may be concluded that it would have been wise for the Seventh Circuit at least to have considered the need for a substitute limiting standard.

Such a limitation could follow Birnbaum and limit damages indirectly; that is, it could decrease potential liability by limiting the class of plaintiffs. However, such limitation, because it would only indirectly limit damages, would seem to possess the same flaw as Birnbaum-being at times either over-restrictive (that is, frustrating actions with limited total claims which would otherwise be successful) or under-restrictive (that is, allowing actions with enormous damage claims to succeed). ${ }^{95}$ It would seem instead that the limitation should impose an arbitrary maximum liability for each defendant for every violation of rule $10 \mathrm{~b}-5^{.98}$ Such a limiting standard could employ several degrees of sevcrity, based on the nature of the violation. ${ }^{97}$

LAw. 69, 69-70 (1968). Assuming that the jurisdictional requirements were met, it must be questioned whether the benefits of rule $10 \mathrm{~b}-5$ recovery to sellers of the stock outweigh the harm done the corporation and its shareholders. It must be noted that the sellers were not injured in the normal sense; that is, they were not harmed because segments of the market possessed non-public information. Rather, the sellers did not make as much money as they would have because everyone in the market did not have full information.

95. See note 80 supra and accompanying text.

96. This suggestion is not a novel one for federal securities law. The ALI Federal Securities Code, of which Professor Loss is the reporter, would impose such an arbitrary limitation on total damages for a negligent misstatement or omission in a required filing. Damages against each defendant would be limited to the greatest of (A) $\$ 100,000$, (B) one percent (to a maximum of $\$ 1,000,000$ ) of defendant's gross income in the defendant's last fiscal year, or (C) defendant's profit. ALI Federal SEcuRrtres CODE $\$ 1403(\mathrm{~g})(2)$ (Tent. Draft No. 2, 1973). No such arbitrary limitation is provided for knowing misrepresentations in a filing or for illegal or deceptive sales or purchases, although damages in the latter categories are limited to the extent of the securities sold or bought by the defendant. Id. at $\$ \S 1401(d)(2) \& 1402(f)(2)(B)$.

97. Analogies can be found in other areas of the law in which the degree of culpability affects the size of the damages awarded. In tort, for instance, if the defendant's conduct is particularly outrageous, punitive damages may be awarded; in such a situation, the plaintiff's recovery goes beyond compensation, which is the usual standard for tort recovery. See W. Prosser, supra uote 87, at 9-14. Automobile guest statutes, enacted in over half the states, allow tort recovery from the driver of an automobile by a gratuitous guest only where the driver is guilty of gross negligence. See, e.g., AlA. Code tit. 36, § 95 (1959); Colo. Rev. Stat. Ann. § 13-9-1 (1964); Tex. Rev. Ctv. Stat. ANN. art. 6701(b) (1969). See also W. Prosser, supra, at 186-87. For the handling of similar situations in regard to airplane accidents, see Whitehead, Legal Liability of Owners and Operators of Aircraft in General Aviation for Damages to Third Parties, 15 Syracuse L. Rev. 1, 2-3 (1963). A number of state statutes, dealing with such subjects as bailmeuts, voluntary agencies, acts by public officials, involuntary depositories, and so on, predicate recovery on various degrees of fault. For an old but 
For purely negligent violations ${ }^{98}$ by a corporation, total damages recoverable could be restricted to the greater of the profit made by the defendant due to his fraud or a predetermined percentage ${ }^{00}$ of the defendant corporation's earnings. ${ }^{100}$ If such an approach were utilized, the defendant at a minimum would be forced to yield any profits derived from the violation; if, however, its ability to pay (as measured by the predetermined percentage of its earnings) exceeded the benefit realized, this larger figure would set the limit on damages. For a violation involving gross negligence or wilful misconduct, ${ }^{101}$ the ceiling on liability should be set higher, not merely because such behavior is more reprehensible than mere negligence, but also because in such cases the possible penalty should outweigh the possible profits from the fraud im order to deter corporations and their insiders from coldly gambling that their fraud will go undetected. Thus, maximum liability for gross negligence or wilful misconduct could be limited to a fixed multiple of a defendant corporation's profit from the transaction or a stepped-up percentage of defendant corporation's earnings, whichever was greater. Similar limitations could be established for violations by insiders. ${ }^{102}$

extremely comprehensive review of such statutes, see Elliott, Degrees of Negligence, 6 S. CAL. L. Rev. 91, 127-35 (1933).

98. For a detailed analysis of limitation on $10 \mathrm{~b}-5$ damages for negligently misleading corporate public statements and press releases, see Comment, supra note 90. The Comment suggests two possible methods of limiting liability: one approach would be to limit the total damages recoverable to a percentage of corporate earnings or fix the amount of damages, while allowing them to be paid out of earnings over time. Id. at 172-73. The second approach would be to apportion the loss incurred among the plaintiffs and the stockholders according to their relative equity holdings. Id. at 173-78.

99. This percentage should be high enough to deter the activity yet not be so high as to cripple the corporation.

100. A percentage of earnings approach is utilized because it seems to represent in at least a rough fashion the defendant corporation's ability to pay. A percentage of earnings approach has likewise been employed in a proposed arbitrary limitation on damages for negligent misstatements or admissions in a required finding, ALI FEDERAL SeCuruties CoDE, supra note $96, \S 1403(\mathrm{~g})(2)$, and a proposed limitation on negligent public releases by corporations, Comment, supra note 90, at 172.

101. It may be questioned whether a limitation on damages for gross negligence or wilful misconduct is appropriate. However, the argument against the wisdom of allowing huge damage liabilities to fall upon defendants, see notes 87-94 supra and accompanying text, would seem to apply regardless of the degrce of culpability of the defendants. Therefore, if a limitation for negligent violations of rule $10 \mathrm{~b}-5$ is found to be appropriate, it would seem to follow that some limitation is likewise needed in cases involving higher levels of culpability. Of course, it is important that the limitation be set sufficiently high to deter such activity.

102. To be an effective deterrent, the percentage of earnings would probably have to be higher in regards to an individual than a corporation, perhaps even rising to a multiple of the insider's earnings for the previous year. Once again, the final figure 
Under such a scheme, recoveries would be fully compensatory up to the limit on damages applicable to the particular case. Only wlien the total damages rose above this limit would the new standard have any effect; if damages exceeded the amount the defendants were required to pay, all plaintiffs' damages would have to be prorated to keep the total damages recovered within the upper limit. If proration were necessary, class actions ${ }^{103}$ could be employed to insure that all injured parties would share in the recovery, rather than allowing relief to operate on a first-come, first-served basis with plaintiffs recovering initially having their claims satisfied in full and subsequent plaintiffs receiving little or no recovery. In the alternative, some form of interpleader could be utilized, ${ }^{104}$ with the maximum amount recoverable placed in the hands of a court subject to division among all successful plaintiffs. ${ }^{105}$

A standard of this nature would preserve the in terrorem effect of rule 10b-5 while eliminating the possibility of crushing liability. An objection might be raised that rule 10b-5 has traditionally been viewed as compensatory in nature and that a corporation or individual defendant found guilty of fraud should be required to compensate plaintiffs without regard to the detriment resulting to the defendant. However, the current problems inherent in rule 10b-5 demonstrate that compensation of plaintiffs should not be the sole consideration. ${ }^{106}$ It would seem that a $10 \mathrm{~b}-5$ standard which could deter fraudulent activity while at the same time reducing the possibility of crippling the defendant would be inore satisfactory than the present system, in which compensation is allowed to plaintiffs without regard to the defendant's ability to pay. Further, the flaws inherent in the present administration of rule 10b-5 will be exacerbated by the absence of the Birnbaum limitation brought about by Eason.

In the fimal analysis, the decision whether the Birnbaum doctrine should be replaced by a new limiting standard ought to be based on

should be set at a level high enough to deter insiders from engaging in fraudulent activity yet not so high as to prove ruinous.

103. See FED. R. Crv. P. 23.

104. See FED. R. Crv. P. 22.

105. The mechanics of proration of damages are similarly provided for in ALI FEDERAL SECURITIES CODE, supra note 96, $\$ 1409$. For examples of arbitrary limitations of damages in other areas of the law and the procedures used to distribute ratably the damage awards, see Atomic Energy Act $\S \S 170(e),(o), 42$ U.S.C. $\$ \S 2210(e),(o)$ (1970) (liability for nuclear accidents); FED. R. Crv. P. Supplemental Rule F (admiralty and maritime claims).

106. See notes 87-94 supra and accompanying text. 
an examination of the policies behind rule 10b-5. Ideally, such an analysis should entail a fresh consideration of rule $10 \mathrm{~b}-5$ in light of its present day status. The suggestions advanced by this Note are not intended to be coinprehensive, but rather are presented as illustrative of the type of analysis that should be einployed. In Eason, the Seventh Circuit took the significant and laudable step of becoming the first circuit court to reject the Birnbaum doctrine. The decision is disappointing, however, in that the court made no attempt to gauge the effect that the elimination of the purchaser-seller requirement will have on rule 10b-5 actions or to do more than trust to future litigation to determine the appropriate limits to the rule.

The great expansion of rule $10 \mathrm{~b}-5$ has been caused by a history of extrennely liberal judicial interpretations of the rule. If this longstanding judicial policy las created difficulties, the courts should be willing to attempt to alleviate the problems, even if this should entail innovative steps, such as the judicial creation of an arbitrary limitation on damages. However, precedents for court-imposed limitations on damages are $\mathrm{few}^{107}$ and judicial caution will quite likely result im no such judicial creation of an arbitrary limitation on damages. ${ }^{108}$ Further, although the SEC under its rulemaking power undoubtedly has the power to amend rule 10b-5 to include such a limitation, ${ }^{109}$ such action seems highly unlikely, ${ }^{110}$ given the SEC's traditional advocacy of an expansive view of rule $10 \mathrm{~b}-5$ and the controversy such a step would arouse. Therefore, if Eason is followed in other circuits, ${ }^{111}$ and a new limitation on rule $10 \mathrm{~b}-5$ thus becomes an even

107. One commentator cites the judicially ordered change from contributory to comparative negligence in Georgia and the traditional rule of apportionment of damages according to fault in admiralty cases as precedents for a judicial limitation on damages. Comment, supra note 90, at 180 . He concludes that "[w]hile there is little direct support for judicial apportionment of losses, there are no bars to such apportionment. If cogent arguments can be advanced in support of limitation of damages through the apportionment of losses, courts should respond to those arguments by adopting such a scheme." Id. at 181.

108. The reluctance of the Supreme Court to move forcefully to bring order out of the current chaotic status of rule 10b-5 can be seen in the denial of certiorari in Eason. See 42 U.S.L.W. 3609 (U.S. Apr. 22, 1974). This was done despite the clear conflict over the purchaser-seller requirement in the circuits. On the same day the Court dcnied certiorari in Eason, it demied certiorari in a case which had upheld the Birnbaum doctrine. Landy v. FDIC, 486 F.2d 139 (3d Cir. 1973), cert. denied, 42 U.S.L.W. 3593 (U.S. Apr. 22, 1974).

109. See note 14 supra and accompanying text.

110. See Bradford, supra note 73, at 222; Marsh, supra note 94, at 75.

111. Since Eason was decided, the Fifth Circuit has stated that "we expressly reaffirm the vitality of the purchaser-seller requirement in this circuit." Sargent v. Genesco, Inc., 42 U.S.L.W. 2552, 2553 (5th Cir. Apr. 11, 1974). 
more compelling need, it would seem likely that the creation of such a limitation will be left to Congress, which could implement such a limitation by amendment to the Exchange Act. Given the present status of rule $10 \mathrm{~b}-5$, it is to be hoped that the courts, Congress and the SEC will consider the need for a new doctrine limiting damages under rule 10b-5. 